\section{Functional Characterization of the Alpha Adrenergic Receptor Modulating the Hydroosmotic Effect of Vasopressin on the Rabbit Cortical Collecting Tubule}

Radha K. Krothapalli and Wadi N. Suki

Renal Section, Department of Medicine, Baylor College of Medicine, The Methodist Hospital, and Veterans Administration Medical Center, Houston, Texas 77211 bstract. To characterize the type of alpha adrenergic receptor, the effects of specific alpha adrenergic agonists and antagonists on antidiuretic hormone ([ $\left.\mathrm{Arg}^{8}\right]-$ vasopressin [AVP])-induced water absorption were evaluated in cortical collecting tubules isolated from the rabbit kidney and perfused in vitro. In the presence of AVP $(100 \mu \mathrm{U} / \mathrm{ml})$, net fluid volume absorption $\left(J_{\mathrm{v}}\right.$, nanoliters per minute per millimeter) was $1.39 \pm 0.09$ and osmotic water permeability coefficient $\left(\mathrm{P}_{\mathrm{f}}, \times 10^{-4}\right.$ centimeters per second) was $150.2 \pm 15.0$. The addition of $10^{-6} \mathrm{M}$ phenylephrine (PE), an alpha adrenergic agonist, resulted in a significant decrease in $J_{v}$ and $P_{f}$ to $0.72 \pm 0.11(P$ $<0.005)$ and $69.9 \pm 10.9(P<0.005)$. The addition of $10^{-4} \mathrm{M}$ prazosin (PZ), an alpha ${ }_{1}$ adrenergic antagonist, did not cause any significant change in $J_{v}$ and $P_{f}$, which were $0.71 \pm 0.09(P=\mathrm{NS}$ vs. AVP $+\mathrm{PE})$ and $67.8 \pm 9.5$ $(P=\mathrm{NS}$ vs. AVP $+\mathrm{PE})$, respectively. In a separate group of tubules, in the presence of AVP $(100 \mu \mathrm{U} / \mathrm{ml})$ and PE $\left(10^{-6} \mathrm{M}\right), J_{v}$ and $P_{f}$ were $0.78 \pm 0.17$ and $76.1 \pm 18.0$, respectively. The addition of $10^{-6} \mathrm{M}$ yohimbine (Y), an alpha $_{2}$ adrenergic antagonist, resulted in a significant increase in $J_{\mathrm{v}}$ to $1.46 \pm 0.14(P<0.01)$ and $P_{\mathrm{f}}$ to $157.5 \pm 22.3$ $(P<0.005)$. Y $\left(10^{-4} \mathrm{M}\right)$ or $\mathrm{PZ}\left(10^{-4} \mathrm{M}\right)$ alone did not significantly affect $J_{\mathrm{v}}$ and $\mathrm{P}_{\mathrm{f}}$ in the presence of AVP (100 $\mu \mathrm{U} / \mathrm{ml})$.

The effect of the natural endogenous catecholamine norepinephrine (NE) on $J_{\mathrm{v}}$ and $\mathrm{P}_{\mathrm{f}}$ in the presence of AVP

Dr. Krothapalli was a postdoctoral Fellow of the National Kidney Foundation during the course of these studies.

Received for publication 14 June 1983 and in revised form 22 November 1983.

J. Clin. Invest.

(c) The American Society for Clinical Investigation, Inc. 0021-9738/84/03/0740/10 \$1.00

Volume 73, March 1984, 740-749 and propranolol (PR) was next examined. $J_{v}$ and $P_{f}$ were $1.53 \pm 0.07$ and $176.3 \pm 5.2$, respectively, in the presence of AVP $(100 \mu \mathrm{U} / \mathrm{ml})$ and PR $\left(10^{-4} \mathrm{M}\right)$. The addition of NE $\left(10^{-8} \mathrm{M}\right)$ resulted in a significant decrease in $J_{v}$ to $1.19 \pm 0.11(P<0.05)$ and $P_{\mathrm{f}}$ to $127.0 \pm 11.3(P<0.02)$. Increasing the concentration of $N E$ to $10^{-6} \mathrm{M}$ resulted in a further decrease in $J_{v}$ and $P_{f}$ to $0.70 \pm 0.10(P<0.01$ vs. NE $\left.10^{-8} \mathrm{M}\right)$ and $68.5 \pm 10.6\left(P<0.01\right.$ vs. NE $10^{-8}$ $M)$, respectively. The inhibitory effect of NE on AVPinduced water absorption was blocked by $\mathrm{Y}$, but not by $\mathrm{PZ}$.

The effect of the alpha ${ }_{2}$ adrenergic agonist clonidine (CD) on $J_{v}$ and $P_{f}$ was also examined. In the presence of $\operatorname{AVP}(10 \mu \mathrm{U} / \mathrm{ml}), J_{v}$ and $P_{f}$ were $1.65 \pm 0.04$ and $175.1 \pm 13.1$, respectively. The addition of $\mathrm{CD}\left(10^{-6} \mathrm{M}\right)$ resulted in a significant decrease in $J_{\mathrm{v}}$ to $1.08 \pm 0.12$ $(P<0.01)$ and $P_{f}$ to $108.1 \pm 15.4(P<0.01)$. Increasing the concentration of $C D$ to $10^{-4} \mathrm{M}$ resulted in a further significant decrease in $J_{\mathrm{v}}$ and $\mathrm{P}_{\mathrm{f}}$ to $0.57 \pm 0.13(P<0.02$ vs. $\left.C D 10^{-6} \mathrm{M}\right)$ and $54.7 \pm 13.8\left(P<0.01\right.$ vs. $\mathrm{CD} 10^{-6}$ $M)$, respectively. Similar results were obtained in the presence of AVP (100 $\mu \mathrm{U} / \mathrm{ml})$. The inhibitory effect of CD on AVP-induced water absorption was blocked by $Y$. CD did not significantly affect $J_{v}$ and $P_{f}$ in the presence of 8-bromo adenosine $3^{\prime}, 5^{\prime}$-cyclic monophosphate.

These studies indicate that alpha adrenergic agonists directly inhibit AVP-mediated water absorption at the level of the renal tubule, an effect that can be blocked by specific alpha ${ }_{2}$ adrenergic antagonists, but not by specific alpha ${ }_{1}$ adrenergic antagonists. Alpha 2 adrenergic stimulation directly inhibits AVP-mediated water absorption at the level of the tubule, an effect that can be blocked by a specific alpha ${ }_{2}$ adrenergic antagonist. This effect appears to be exerted at the level of activation of adenylate cyclase, since it is absent in the presence of cyclic AMP. 


\section{Introduction}

There is considerable evidence to suggest that alpha adrenergic stimulation causes an increase in free water clearance $\left(\mathrm{C}_{\mathrm{H}_{2} \mathrm{O}}\right)^{1}$ (1). The exact mechanism by which catecholamines modulate water excretion, however, is unclear. Some studies have suggested that they cause changes in water excretion by modifying the release of endogenous vasopressin (1). Other studies, however, have suggested that catecholamines modulate the action of antidiuretic hormone at the cellular level (1). Clonidine (CD), a known alpha ${ }_{2}$ adrenergic agonist, has also been shown to cause water diuresis (2-8). The exact mechanism by which CD causes changes in water excretion is not definitely established, but both suppression of vasopressin release and modulation of its renal effect have been proposed (2-8).

Recently, we have demonstrated that the alpha adrenergic agonist phenylephrine (PE) directly inhibits antidiuretic hormone-induced water absorption at the tubular level (9). We have also shown that this effect can be blocked by phentolamine, a known alpha adrenergic antagonist (9). However, it was not known whether the natural catecholamine, norepinephrine (NE), would exert a similar effect on antidiuretic hormone-induced water absorption in the cortical collecting tubule (CCT) and whether the effect of the alpha adrenergic agonists is mediated by alpha ${ }_{1}$ or alpha $a_{2}$ adrenergic receptors or both. Therefore, the present studies were performed to characterize the specific alpha adrenergic receptor responsible for modulating the action of antidiuretic hormone on water absorption in isolated CCT of the rabbit, perfused in vitro. In addition, studies were conducted to directly examine the effects of NE and of $\mathrm{CD}$ on water absorption in the CCT.

\section{Methods}

Segments of CCT were isolated and perfused in vitro as described by Burg et al. (10) with few modifications (9). Briefly, experiments were performed on female New Zealand white rabbits weighing 1.5-2.5 kg that had been maintained on tap water and rabbit chow until the time of study. Animals were killed by decapitation and the right kidney was removed, decapsulated, and sliced into transverse sections, 1-2-mm thick. The slices were transferred to a dish containing chilled dissecting solution of the following composition (in millimolar): $\mathrm{NaCl}, 140$; $\mathrm{K}_{2} \mathrm{HPO}_{4}, 2.5 ; \mathrm{MgSO}_{4}, 1.2$; L-alanine, 6.0 ; sodium citrate, 1.0 ; sodium lactate, $4.0 ; \mathrm{CaCl}_{2}, 2.0$; and glucose 5.5. The $\mathrm{pH}$ of the solution was 7.4 and osmolality was $290 \mathrm{mosmol} / \mathrm{kg} \mathrm{H}_{2} \mathrm{O} .5 \%$ (vol/vol) of $5 \mathrm{~g} / \mathrm{dl}$ defatted bovine albumin (Calbiochem-Behring Corp., La Jolla, CA) solution was added to prevent adhesion of tubules to the dish. CCT (1.0$2.5 \mathrm{~mm}$ in length) were teased from the slices with fine dissecting forceps.

1. Abbreviations used in this paper: AVP, $\left(\mathrm{Arg}^{8}\right)$-vasopressin; 8-BrcAMP, 8-bromo adenosine 3',5'-cyclic monophosphate; CCT, cortical collecting tubule; $C D$, clonidine; $\mathrm{C}_{\mathrm{H}_{2} \mathrm{O}}$, free water clearance; $J_{v}$, net fluid absorption; $\mathrm{NE}$, norepinephrine; $\mathrm{P}_{\mathrm{f}}$, osmotic water permeability coefficient; $V_{\mathrm{i}}$, perfusion rate; PE, phenylephrine; PR, propranolol; PZ, prazosin; Y, yohimbine.
Only the ends of the tubule segments were touched, and these were subsequently trimmed.

The tubules were transferred to a Lucite perfusion chamber mounted on the mechanical stage of an inverted microscope. The chamber contained a bathing solution identical to the dissecting solution. One end of the tubule was aspirated into a constriction pipette and an inner, concentric perfusion pipette containing the perfusate was advanced into the lumen of the tubule. Perfusion was initiated by a gravity flow-system at a rate of $5-15 \mathrm{nl} / \mathrm{min}$. The luminal perfusion solution contained (in millimolar): $\mathrm{NaCl}, 60 ; \mathrm{K}_{2} \mathrm{HPO}_{4}, 2.5 ; \mathrm{MgSO}_{4}, 1.2$; and $\mathrm{CaCl}_{2}, 2.0$. The $\mathrm{pH}$ was 7.4 and the osmolality was $125 \mathrm{mosmol} / \mathrm{kg} \mathrm{H}_{2} \mathrm{O}$. Exhaustively dialyzed [methoxy ${ }_{-}^{3} \mathrm{H}$ ] inulin (New England Nuclear, Boston, MA) was added to the perfusate as a volume marker. The other end of the tubule was aspirated into a collecting pipette coated with Sylgard 184 silicone elastomer (Dow Corning Corp., Midland, MI). Mineral oil was layered over the collected fluid to prevent evaporation. The tubules were inspected visually and length was determined by using an eyepiece micrometer. Tubules were discarded if any breaks or denuded areas were visible along the perfused length. Tubules were also discarded if there was a leakage rate of $\left[{ }^{3} \mathrm{H}\right]$ inulin into the bathing solution in excess of $1 \%$ of the perfusion rate. The bathing solution was then replaced by another solution of the following composition (in millimolar): $\mathrm{NaCl}, 115$; $\mathrm{NaHCO}_{3}, 25 ; \mathrm{K}_{2} \mathrm{HPO}_{4}, 2.5 ; \mathrm{MgSO}_{4}, 1.2 ;$ L-alanine, 6.0 ; sodium citrate, 1.0 ; sodium lactate, $4.0 ; \mathrm{CaCl}_{2}, 2.0$; and glucose, $5.5 .5 \%$ ( $\mathrm{vol} / \mathrm{vol}$ ) of 5 $\mathrm{g} / \mathrm{dl}$ defatted bovine albumin solution was added to the bathing solution. The $\mathrm{pH}$ of the bathing solution was maintained at 7.4 by continuous bubbling with $95 \% \mathrm{O}_{2} / 5 \% \mathrm{CO}_{2}$. The osmolality of the bathing solution was $290 \mathrm{mosmol} / \mathrm{kg} \mathrm{H}_{2} \mathrm{O}$. The bathing solution was continuously changed at a rate of $0.5 \mathrm{ml} / \mathrm{min}$ using a Holter pump (Extracorporeal Medical Specialties, King of Prussia, PA). Bath temperature was maintained at $25^{\circ} \mathrm{C}$ in all the experiments.

Timed samples were collected under oil into constant-volume pipettes that had been advanced into the collecting pipettes. Each sample was placed in $5 \mathrm{ml}$ of Biofluor (New England Nuclear) and radioactivity was measured in a Tri-Carb liquid scintillation counter (Packard Instruments Co., Downers Grove, IL).

$\left(\mathrm{Arg}^{8}\right)^{8}$-vasopressin (AVP) acetate was obtained from CalbiochemBehring Corp; $\mathrm{PE} \mathrm{HCl}, \mathrm{NE}$ bitartrate, yohimbine (Y) $\mathrm{HCl}$, and 8-bromo adenosine $3^{\prime}, 5^{\prime}$-cyclic monophosphate (8-BrcAMP) were obtained from Sigma Chemical Co., St. Louis, MO; propranolol (PR) HCl was obtained from Ayerst Laboratories Inc., New York; $\mathrm{CD} \mathrm{HCl}$ was a kind gift from Boehringer Ingelheim Ltd., Ridgefield, CT; and prazosin (PZ) $\mathrm{HCl}$ was a kind gift from Dr. Eugene Weiss of Pfizer Laboratories, New York. All solutions were prepared daily and added in desired concentration to the bathing solution only, just before commencement of the experiment. NE was kept in a dark container in a refrigerator until needed. The amount of PZ that was necessary to achieve the desired concentration was directly added to the bathing solution and the solution was mixed thoroughly for $1 \mathrm{~h}$ using the ultrasonic sonicator (Heat Systems-Ultrasonics Inc., Plainview, NY) to ensure complete dissolution of PZ.

Perfusion of the tubules was initiated within $30 \mathrm{~min}$ from the time of decapitation in most of the experiments. In all the experiments, an initial equilibration period of 120-150 min was allowed to elapse from the time of decapitation to ensure the disappearance of the effects of endogenous vasopressin. In between the experimental periods, a stabilization period of $30-45 \mathrm{~min}$ was maintained. The following groups of experiments were performed.

Group I. Effect of PE and PZ on AVP-induced water absorption. After the initial equilibration period, AVP was added to the bathing solution in a concentration of $100 \mu \mathrm{U} / \mathrm{ml}$. After a stabilization period, 
timed samples of collected fluid were obtained. PE $\left(10^{-6} \mathrm{M}\right)$, an alpha adrenergic agonist, was then added to the bathing solution containing AVP, and samples of collected fluid were obtained after another stabilization period. $\mathrm{PZ}\left(10^{-4} \mathrm{M}\right)$, an alpha $\mathrm{a}_{1}$ adrenergic antagonist, was then added to the bathing solution containing AVP and PE. Collected fluid samples were obtained again after the stabilization period. $\mathrm{PZ}$ and $P E$ were then removed from the bath and another set of collected fluid samples was obtained in the presence of AVP only.

Group II. Effect of $P E$ and $Y$ on AVP-induced water absorption. After the initial equilibration period, AVP $(100 \mu \mathrm{U} / \mathrm{ml})$ was added to the bathing solution and collected fluid samples were obtained as in group I. PE $\left(10^{-6} \mathrm{M}\right)$ was then added to the bathing solution and samples of collected fluid were obtained. Y $\left(10^{-6} \mathrm{M}\right)$, an alpha ${ }_{2}$ adrenergic antagonist was then added to the bathing solution containing AVP and $P E$ and timed samples of collected fluid were obtained. The effect of $Y$ $\left(10^{-5} \mathrm{M}\right)$ was similarly studied in a fourth experimental period.

Group III. Effect of NE on AVP-induced water absorption in PRtreated tubules. To be sure that the natural endogenous catecholamines exerted the same effect as PE, this group of experiments was performed using NE. After the initial equilibration period, AVP $(100 \mu \mathrm{U} / \mathrm{ml})$ and PR $\left(10^{-4} \mathrm{M}\right)$ were added to the bathing solution. Timed samples of collected fluid were obtained after a stabilization period. NE $\left(10^{-8} \mathrm{M}\right)$ was then added to the bathing solution and collected fluid samples were obtained. The dose-response relationship of NE to AVP-induced water absorption in PR-treated tubules was examined by adding progressively increasing concentrations of $\mathrm{NE}$ (from $10^{-8} \mathrm{M}$ to $10^{-5} \mathrm{M}$ ) to the bathing solution. When NE $\left(10^{-4} \mathrm{M}\right)$ was added to the bathing solution, irreversible cellular damage occurred.

Group IV. Effect of NE and PZ on AVP-induced water absorption. The experimental protocol was same as in group I except that NE $\left(10^{-6} \mathrm{M}\right)$ was used in this group instead of PE $\left(10^{-6} \mathrm{M}\right)$.

Group $V$. Effect of $N E$ and $Y$ on AVP-induced water absorption. The experimental protocol was the same as in group II except that NE $\left(10^{-6} \mathrm{M}\right)$ was used in this group instead of PE $\left(10^{-6} \mathrm{M}\right)$.

Group VI. Effect of CD on AVP-induced water absorption. (a) After the initial equilibration period, AVP $(10 \mu \mathrm{U} / \mathrm{ml})$ was added to the bathing solution and timed samples of collected fluid were obtained after a stabilization period. $\mathrm{CD}\left(10^{-6} \mathrm{M}\right)$ was then added to the bathing solution and collected fluid samples were again obtained after the stabilization period. The effect of $\operatorname{CD}\left(10^{-5}\right.$ and $\left.10^{-4} \mathrm{M}\right)$ on $\operatorname{AVP}(10 \mu \mathrm{U} / \mathrm{ml})$-induced water absorption was similarly studied in subsequent experimental periods. $\mathrm{CD}$ was then removed from the bathing solution and collected fluid samples were obtained in the presence of AVP $(10 \mu \mathrm{U} / \mathrm{ml})$ only. (b) The experimental protocol was same as in group VIa except that AVP was used in a concentration of $100 \mu \mathrm{U} / \mathrm{ml}$.

Group VII. Effect of CD and $Y$ on AVP-induced water absorption. After an initial equilibration period, AVP was added to the bathing solution in a concentration of $100 \mu \mathrm{U} / \mathrm{ml}$. After obtaining collected fluid samples, $\mathrm{CD}\left(10^{-4} \mathrm{M}\right)$ was added to the bathing solution containing AVP. After another stabilization period, collected fluid samples were obtained. $Y\left(10^{-5} \mathrm{M}\right)$ was then added to the bathing solution containing AVP and CD and samples of the collected fluid were obtained. The effect of $Y\left(10^{-4} \mathrm{M}\right)$ was similarly examined in a fourth experimental period.

Group VIII. Effect of CD on cyclic AMP-induced water absorption. In this group of tubules, 8-BrcAMP $\left(10^{-4} \mathrm{M}\right)$ was added to the bathing solution initially. After obtaining the collected fluid samples, CD $\left(10^{-4} \mathrm{M}\right)$ was then added to the bathing solution containing 8-BrcAMP and collected fluid samples were obtained.

Group IX. Effect of PZ, PR, and Y on AVP-induced water absorption.
After obtaining samples of the collected fluid in the presence of AVP $(100 \mu \mathrm{U} / \mathrm{ml})$, as in the other groups, PZ $\left(10^{-4} \mathrm{M}\right), \mathrm{PR}\left(10^{-4} \mathrm{M}\right)$, and $\mathrm{Y}\left(10^{-4} \mathrm{M}\right)$ were added separately to the bathing solution containing AVP during the subsequent experimental periods. Collected fluid samples were obtained in each experimental period.

Calculations. Net fluid absorption $\left(J_{\mathrm{v}}\right)$ was calculated using the formula: $J_{\mathrm{v}}(\mathrm{nl} / \mathrm{min} / \mathrm{mm})=\left(V_{\mathrm{i}}-V_{0}\right) / L$, where $V_{\mathrm{i}}$ is the perfusion rate in nanoliters per minute, $V_{0}$ is the collection rate in nanoliters per minute, and $L$ is the length of the tubule in millimeters.

$V_{\mathrm{i}}$ was calculated from the formula: $V_{\mathrm{i}}=V_{0} \cdot\left[{ }^{3} \mathrm{H}_{0}\right] /\left[{ }^{3} \mathrm{H}_{\mathrm{i}}\right]$, where $\left[{ }^{3} \mathrm{H}_{0}\right]$ and $\left[{ }^{3} \mathrm{H}_{i}\right]$ are the inulin counts per nanoliter in the collected and perfused fluids, respectively.

The osmotic water permeability coefficient, $P_{f}\left(\mathrm{~cm} \cdot \mathrm{s}^{-1}\right)$ was calculated using the formula (11):

$$
\mathrm{P}_{\mathrm{f}}=-\frac{V_{\mathrm{i}} C_{0}}{A \cdot \bar{V}_{\mathrm{w}}}\left[\frac{C_{0}-C_{1}}{C_{0} \cdot C_{1} \cdot C_{\mathrm{b}}}+\frac{1}{\left(C_{\mathrm{b}}\right)^{2}} \ln \frac{\left(C_{1}-C_{\mathrm{b}}\right) C_{0}}{\left(C_{0}-C_{\mathrm{b}}\right) C_{\mathrm{l}}}\right]
$$

where $V_{\mathrm{i}}$ is the perfusion rate in cubic centimeters per second, $A$ is the tubule luminal surface area (calculated from the measured length and an arbitrarily assumed diameter of $20 \mu \mathrm{m}$ ), and $\bar{V}_{w}$ is the partial molar volume of water. $C_{0}, C_{\mathrm{b}}$, and $C_{1}$ are the osmolalities of the perfusate, bath, and collected fluid, respectively. Osmolality of the perfusate and bath were measured. Osmolality of the collected fluid was calculated from the measured perfusate osmolality and the relative increase in the concentration of the volume marker measured in the collected fluid.

All values represent the mean of two or more collections for each experimental period. The data are shown as means $\pm \mathrm{SE}$. Statistical analysis was performed by using the $t$ test for paired data (two experimental periods) or by analysis of variance (more than two experimental periods in the same tubule) $(12,13)$.

\section{Results}

Group I. The effect of the alpha adrenergic agonist PE on AVPmediated $J_{v}$ and $P_{f}$ and the effect of the alpha $a_{1}$ adrenergic antagonist $\mathrm{PZ}$ on the decrease in $J_{\mathrm{v}}$ and $\mathrm{P}_{\mathrm{f}}$ caused by $\mathrm{PE}$ are shown in Table I. In this group of tubules $(n=4)$, when AVP was present in the bathing solution in a concentration of $100 \mu \mathrm{U} /$ $\mathrm{ml}, J_{\mathrm{v}}$ averaged $1.39 \pm 0.09 \mathrm{nl} \cdot \mathrm{min}^{-1} \cdot \mathrm{mm}^{-1}$, and $P_{\mathrm{f}}$ averaged $150.2 \pm 15.0 \times 10^{-4} \mathrm{~cm} / \mathrm{s}$. The addition of $\mathrm{PE}\left(10^{-6} \mathrm{M}\right)$ resulted in a significant decrease of $J_{v}$ and $P_{f}$ to $0.72 \pm 0.11$ $\mathrm{nl} \cdot \mathrm{min}^{-1} \cdot \mathrm{mm}^{-1}(P<0.005$ vs. AVP alone $)$ and $69.9 \pm 10.9$ $\times 10^{-4} \mathrm{~cm} / \mathrm{s}(P<0.005$ vs. AVP alone $)$, respectively. When PZ $\left(10^{-4} \mathrm{M}\right)$ was added to the bathing solution containing AVP $(100 \mu \mathrm{U} / \mathrm{ml})$ and $\mathrm{PE}\left(10^{-6} \mathrm{M}\right)$, there was no significant change in $J_{\mathrm{v}}$ and $\mathrm{P}_{\mathrm{f}}$, which were $0.71 \pm 0.09 \mathrm{nl} \cdot \mathrm{min}^{-1} \cdot \mathrm{mm}^{-1}(P=\mathrm{NS}$ vs. AVP + PE) and $67.8 \pm 9.5 \times 10^{-4} \mathrm{~cm} / \mathrm{s}(P=\mathrm{NS}$ vs. AVP + PE), respectively. $J_{v}$ and $P_{f}$ increased to $1.34 \pm 0.11$ $\mathrm{nl} \cdot \mathrm{min}^{-1} \cdot \mathrm{mm}^{-1}(P<0.005$ vs. AVP $+\mathrm{PE}, P<0.005$ vs. AVP $+\mathrm{PE}+\mathrm{PZ})$ and $144.5 \pm 17.1 \times 10^{-4} \mathrm{~cm} / \mathrm{s}(P<0.01$ vs. AVP $+\mathrm{PE}, P<0.005$ vs. AVP $+\mathrm{PE}+\mathrm{PZ}$ ), respectively, when both $\mathrm{PZ}$ and $\mathrm{PE}$ were removed from the bath and the tubules were exposed to AVP $(100 \mu \mathrm{U} / \mathrm{ml})$ alone. These values are not significantly different from the values obtained during the initial experimental period with AVP alone. 
Table I. Effect of PE and PZ on AVP-mediated $J_{v}$ and $P_{f}$ in the CCT of Rabbit

\begin{tabular}{|c|c|c|c|c|c|c|c|c|c|c|c|c|}
\hline & \multicolumn{3}{|c|}{ AVP $100 \mu \mathrm{U} / \mathrm{ml}$} & \multicolumn{3}{|c|}{ AVP $100 \mu \mathrm{U} / \mathrm{ml}+$ PE $10^{-6} \mathrm{M}$} & \multicolumn{3}{|c|}{$\begin{array}{c}\text { AVP } 100 \mu \mathrm{U} / \mathrm{ml}+\mathrm{PE} 10^{-6} \mathrm{M} \\
+\mathrm{PZ} 10^{-4} \mathrm{M}\end{array}$} & \multicolumn{3}{|c|}{ AVP $100 \mu \mathrm{U} / \mathrm{ml}$} \\
\hline & $J_{\mathrm{v}}$ & $\mathbf{P}_{\mathbf{f}}$ & $v_{\mathrm{i}}$ & $J_{\mathrm{v}}$ & $\mathbf{P}_{\mathbf{f}}$ & $V_{\mathrm{i}}$ & $J_{\mathrm{v}}$ & $\mathbf{P}_{\mathbf{f}}$ & $V_{\mathrm{i}}$ & $J_{\mathrm{v}}$ & $\mathbf{P}_{\mathbf{f}}$ & $V_{\mathrm{i}}$ \\
\hline & 1.57 & 183.3 & 10.3 & 0.83 & 81.8 & 10.3 & 0.75 & 72.2 & 11.5 & 1.53 & 181.5 & 9.8 \\
\hline & 1.16 & 113.0 & 12.9 & 0.43 & 40.0 & 13.7 & 0.49 & 45.2 & 13.3 & 1.04 & 100.6 & 13.3 \\
\hline & 1.37 & 142.0 & 8.9 & 0.92 & 89.6 & 8.4 & 0.92 & 90.9 & 7.9 & 1.49 & 157.1 & 8.9 \\
\hline & 1.47 & 162.4 & 8.5 & 0.71 & 68.2 & 9.0 & 0.66 & 62.9 & 8.2 & 1.31 & 138.8 & 8.7 \\
\hline Mean & 1.39 & 150.2 & 10.2 & $0.72^{*}$ & $69.9^{*}$ & $10.4 \ddagger$ & $0.71 \S$ & $67.8 \S$ & $10.2 \ddagger$ & $1.34 \ddagger^{\prime \prime}$ & $144.5 \ddagger^{\prime \prime}$ & $10.2 \ddagger$ \\
\hline$\pm \mathrm{SE}$ & 0.09 & 15.0 & 1.0 & 0.11 & 10.9 & 1.2 & 0.09 & 9.5 & 1.3 & 0.11 & 17.1 & 1.1 \\
\hline
\end{tabular}

Tubules were studied at $25^{\circ} \mathrm{C}$ with a $165 \mathrm{mosmol} / \mathrm{kg} \mathrm{H}_{2} \mathrm{O}$ transepithelial osmotic gradient. $J_{\mathrm{v}}$ is given in nanoliters per minute per millimeter; $\mathrm{P}_{\mathrm{f}}$, in $\times 10^{-4}$ centimeters per second; and $V_{\mathrm{i}}$, in nanoliters per minute. Mean length of the tubules is $2.2 \mathrm{~mm}$. ${ }^{*} P<0.005$ vs. AVP alone. $\ddagger P=$ not significant vs. AVP alone. $\S P=$ not significant vs. AVP $+\mathrm{PE} 10^{-6} \mathrm{M}$. $" P<0.005$ vs. AVP $+\mathrm{PE} 10^{-6} \mathrm{M}+\mathrm{PZ} 10^{-4} \mathrm{M}$.

Group II. The effect of PE on AVP-mediated $J_{\mathrm{v}}$ and $\mathrm{P}_{\mathrm{f}}$ and the effect of the alpha $a_{2}$ adrenergic antagonist $\mathrm{Y}$ on the decrease in $J_{\mathrm{v}}$ and $\mathrm{P}_{\mathrm{f}}$ caused by PE are depicted in Fig. 1. In this group of tubules $(n=4), J_{\mathrm{v}}$ and $\mathrm{P}_{\mathrm{f}}$ averaged $1.48 \pm 0.08 \mathrm{nl} \cdot \mathrm{min}^{-1} \cdot \mathrm{mm}^{-1}$ and $157.7 \pm 12.8 \times 10^{-4} \mathrm{~cm} / \mathrm{s}$, respectively, in the presence of AVP $(100 \mu \mathrm{U} / \mathrm{ml})$ alone. As in group $I$, the addition of PE $\left(10^{-6} \mathrm{M}\right)$ resulted in a significant decrease in $J_{\mathrm{v}}$ and $\mathrm{P}_{\mathrm{f}}$ to $0.78 \pm 0.17 \mathrm{nl} \cdot \mathrm{min}^{-1} \cdot \mathrm{mm}^{-1}(P<0.005$ vs. AVP alone $)$ and $76.1 \pm 18.0 \times 10^{-4} \mathrm{~cm} / \mathrm{s}(P<0.005$ vs. AVP alone $)$, respectively. However, the addition of $\mathrm{Y}\left(10^{-6} \mathrm{M}\right)$ to the bathing solution containing AVP and PE resulted in a significant increase in $J_{\mathrm{v}}$ to $1.46 \pm 0.14 \mathrm{nl} \cdot \mathrm{min}^{-1} \cdot \mathrm{mm}^{-1}(P<0.01$ vs. AVP $+\mathrm{PE}, P$ $=\mathrm{NS}$ vs. AVP alone) and $\mathrm{P}_{\mathrm{f}}$ increased to $157.5 \pm 22.3 \times 10^{-4}$

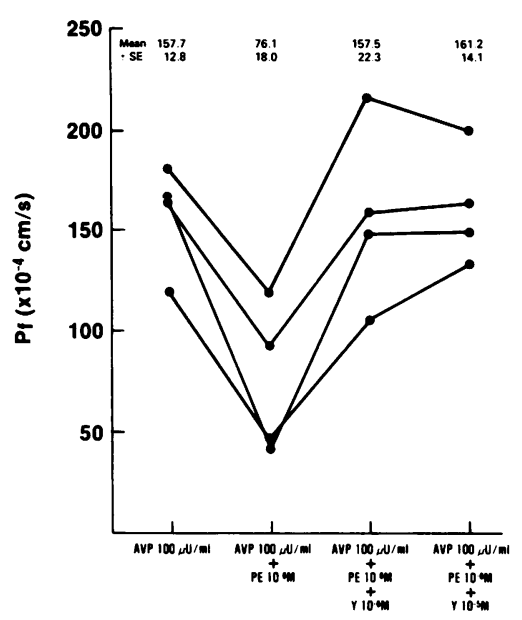

Figure 1. Effect of $\mathrm{PE}$ and $\mathrm{Y}$ on AVP-mediated water absorption in the CCT of rabbit. Mean length of the tubules is $2.0 \mathrm{~mm}$. There was no difference in the perfusion rate between the different experimental periods. Tubules were studied at $25^{\circ} \mathrm{C}$ with a $165 \mathrm{mosmol} / \mathrm{kg} \mathrm{H}_{2} \mathrm{O}$ transepithelial osmotic gradient. Closed circles and solid lines represent the values in individual tubules. Numbers on the top represent the mean $\pm \mathrm{SE}$ of the observations for the corresponding period. $\mathrm{cm} / \mathrm{s} .(P<0.005$ vs. AVP $+\mathrm{PE}, P=\mathrm{NS}$ vs. AVP alone). When the concentration of $\mathrm{Y}$ was increased to $10^{-5} \mathrm{M}$ there was no further increase in $J_{v}$ and $P_{f}$, which were $1.50 \pm 0.08$ $\mathrm{nl} \cdot \mathrm{min}^{-1} \cdot \mathrm{mm}^{-1}\left(P=\mathrm{NS}\right.$ vs. $\left.\mathrm{Y} 10^{-6} \mathrm{M}\right)$ and $161.2 \pm 14.1$ $\times 10^{-4} \mathrm{~cm} / \mathrm{s}\left(P=\mathrm{NS}\right.$ vs. Y $\left.10^{-6} \mathrm{M}\right)$, respectively.

Group III. In this group of tubules $(n=4)$, we examined whether NE, a native catecholamine, has a similar effect as that of PE on AVP-induced $J_{v}$ and $\mathrm{P}_{\mathrm{f}}$. To block the beta adrenergic effects of NE, PR was added throughout the experiment to the bathing solution in a concentration of $10^{-4} \mathrm{M}$. As shown in Table II, $J_{\mathrm{v}}$ and $\mathrm{P}_{\mathrm{f}}$ were $1.53 \pm 0.07 \mathrm{nl} \cdot \mathrm{min}^{-1} \cdot \mathrm{mm}^{-1}$ and $176.3 \pm 5.2 \times 10^{-4} \mathrm{~cm} / \mathrm{s}$, respectively, in the presence of $P R$ $\left(10^{-4} \mathrm{M}\right)$ and AVP $(100 \mu \mathrm{U} / \mathrm{ml})$. The addition of $\mathrm{NE}\left(10^{-8} \mathrm{M}\right)$ to the bathing solution containing $P R$ and AVP resulted in a significant decrease in $J_{\mathrm{v}}$ to $1.19 \pm 0.11 \mathrm{nl} \cdot \mathrm{min}^{-1} \cdot \mathrm{mm}^{-1}(P$ $<0.05$ vs. $\mathrm{PR}+\mathrm{AVP})$ and in $\mathrm{P}_{\mathrm{f}}$ to $127.0 \pm 11.3 \times 10^{-4}$ $\mathrm{cm} \cdot \mathrm{s}^{-1}(P<0.02$ vs. PR + AVP). Increasing the concentration of $\mathrm{NE}$ to $10^{-7} \mathrm{M}$ resulted in a further but not significant decrease in $J_{\mathrm{v}}$ and $\mathrm{P}_{\mathrm{f}}$ to $0.95 \pm 0.13 \mathrm{nl} \cdot \mathrm{min}^{-1} \cdot \mathrm{mm}^{-1}(P=\mathrm{NS}$ vs. NE $10^{-8} \mathrm{M}, P<0.01$ vs. PR + AVP) and $98.0 \pm 14.5 \times 10^{-4} \mathrm{~cm} /$ $\mathrm{s}\left(P=\mathrm{NS}\right.$ vs. NE $10^{-8} \mathrm{M}, P<0.005$ vs. PR $\left.+\mathrm{AVP}\right)$, respectively. Increasing the concentration of $\mathrm{NE}$ to $10^{-6} \mathrm{M}$, however, resulted in a significant decrease in $J_{\mathrm{v}}$ to $0.70 \pm 0.10 \mathrm{nl} \cdot \mathrm{min}^{-1} \cdot \mathrm{mm}^{-1}(P$ $<0.01$ vs. NE $\left.10^{-8} \mathrm{M}\right)$ and in $P_{\mathrm{f}}$ to $68.5 \pm 10.6 \times 10^{-4} \mathrm{~cm} / \mathrm{s}(P$ $<0.01$ vs. NE $\left.10^{-8} \mathrm{M}\right) . J_{\mathrm{v}}$ and $\mathrm{P}_{\mathrm{f}}$ decreased further to $0.44 \pm 0.07$ $\mathrm{nl} \cdot \mathrm{min}^{-1} \cdot \mathrm{mm}^{-1}\left(P<0.01\right.$ vs. NE $\left.10^{-7} \mathrm{M}\right)$ and $40.7 \pm 6.9$ $\times 10^{-4} \mathrm{~cm} / \mathrm{s}\left(P<0.01\right.$ vs. NE $\left.10^{-7} \mathrm{M}\right)$, respectively, when the concentration of NE was increased to $10^{-5} \mathrm{M}$. With the addition of $\mathrm{NE}$ in a concentration of $10^{-4} \mathrm{M}$, irreversible cellular damage occurred.

Group $I V$. The effect of PZ on NE-induced decrease in $J_{\mathrm{v}}$ and $\mathrm{P}_{\mathrm{f}}$ was examined in this group of tubules $(n=4)$. As shown in Table III, in the presence of AVP $(100 \mu \mathrm{U} / \mathrm{ml}), J_{\mathrm{v}}$ and $P_{\mathrm{f}}$ were $1.46 \pm 0.06 \mathrm{nl} \cdot \mathrm{min}^{-1} \cdot \mathrm{mm}^{-1}$ and $154.0 \pm 4.1 \times 10^{-4} \mathrm{~cm} / \mathrm{s}$, respectively. The addition of $\mathrm{NE}\left(10^{-6} \mathrm{M}\right)$ resulted in a significant decrease in $J_{\mathrm{v}}$ to $0.54 \pm 0.01 \mathrm{nl} \cdot \mathrm{min}^{-1} \cdot \mathrm{mm}^{-1}(P<0.005$ vs. AVP alone $)$ and in $P_{f}$ to $50.5 \pm 1.4 \times 10^{-4} \mathrm{~cm} / \mathrm{s}(P<0.001$ vs. 
Table II. Effect of NE on AVP-mediated $J_{v}$ and $P_{f}$ in the CCT of Rabbit in the Presence of PR $\left(10^{-4} M\right)$

\begin{tabular}{|c|c|c|c|c|c|c|c|c|c|c|c|c|c|c|c|}
\hline & \multicolumn{3}{|c|}{$\mathrm{PR}+\mathrm{AVP} 100 \mu \mathrm{U} / \mathrm{ml}$} & \multicolumn{3}{|c|}{$\begin{aligned} \mathrm{PR} & + \text { AVP } 100 \mu \mathrm{U} / \mathrm{ml} \\
& +\mathrm{NE} 10^{-8} \mathrm{M}\end{aligned}$} & \multicolumn{3}{|c|}{$\begin{array}{c}\mathrm{PR}+\text { AVP } 100 \mu \mathrm{U} / \mathrm{ml} \\
+\mathrm{NE} 10^{-7} \mathrm{M}\end{array}$} & \multicolumn{3}{|c|}{$\begin{aligned} \mathrm{PR} & +\mathrm{AVP} 100 \mu \mathrm{U} / \mathrm{ml} \\
& +\mathrm{NE} 10^{-6} \mathrm{M}\end{aligned}$} & \multicolumn{3}{|c|}{$\begin{array}{c}\mathrm{PR}+\mathrm{AVP} 100 \mu \mathrm{U} / \mathrm{ml} \\
+\mathrm{NE} 10^{-5} \mathrm{M}\end{array}$} \\
\hline & $J_{\mathrm{v}}$ & $\mathbf{P}_{\mathbf{f}}$ & $V_{\mathbf{i}}$ & $J_{v}$ & $\mathbf{P r}_{\mathbf{r}}$ & $V_{\mathrm{i}}$ & $J_{v}$ & $\mathbf{P}_{\mathbf{r}}$ & $V_{\mathbf{i}}$ & $J_{\mathrm{v}}$ & $\mathbf{P r}_{\mathbf{r}}$ & $v_{i}$ & $J_{\mathrm{v}}$ & $\mathbf{P}_{\mathbf{f}}$ & $V_{\mathbf{i}}$ \\
\hline & 1.47 & 180.8 & 8.2 & 0.90 & 96.5 & 6.7 & 0.64 & 65.2 & 6.3 & 0.48 & 46.6 & 7.6 & 0.26 & 24.6 & 6.7 \\
\hline & 1.59 & 180.9 & 9.4 & 1.39 & 150.8 & 9.2 & 1.23 & 131.2 & 8.7 & 0.94 & 94.7 & 9.1 & 0.60 & 56.7 & 9.3 \\
\hline & 1.69 & 182.7 & 12.3 & 1.31 & 133.5 & 12.1 & 0.88 & 84.6 & 12.4 & 0.61 & 57.0 & 12.6 & 0.50 & 46.0 & 12.9 \\
\hline & 1.36 & 160.6 & 8.8 & 1.17 & 127.1 & 9.1 & 1.05 & 111.1 & 8.9 & 0.76 & 75.6 & 9.0 & 0.38 & 35.6 & 9.3 \\
\hline Mean & 1.53 & 176.3 & 9.7 & $1.19^{*}$ & 127.0 & $9.3 \ddagger$ & 0.95 & $98.0 \S$ & $9.1 \ddagger$ & $0.70^{\prime \prime}$ & $68.5^{\prime \prime}$ & $9.6 \ddagger$ & $0.44 \pi$ & $40.7 \pi$ & $9.6 \ddagger$ \\
\hline$\pm \mathrm{SE}$ & 0.07 & 5.2 & 0.9 & 0.11 & 11.3 & 1.1 & 0.13 & 14.5 & 1.3 & 0.10 & 10.6 & 1.1 & 0.07 & 6.9 & 1.3 \\
\hline
\end{tabular}

Tubules were studied at $25^{\circ} \mathrm{C}$ with a $165 \mathrm{mosmol} / \mathrm{kg} \mathrm{H}_{2} \mathrm{O}$ transepithelial osmotic gradient. $J_{\mathrm{v}}$ is given in nanoliters per minute per millimeter; $P_{\mathrm{f}}$, in $\times 10^{-4}$ centimeters per second; and $V_{\mathrm{i}}$, in nanoliters per minute. Mean length of the tubules is $2.4 \mathrm{~mm}$. ${ }^{*} P<0.05$ vs. PR $+\mathrm{AVP}$. $¥ P$ $=$ not significant vs. $\mathrm{PR}+\mathrm{AVP}$. $\S P<0.005$ vs. $\mathrm{PR}+\mathrm{AVP}$. $" P<0.01$ vs. $\mathrm{PR}+\mathrm{AVP}+\mathrm{NE} 10^{-8} \mathrm{M}$. $\uparrow P<0.01$ vs. $\mathrm{PR}+\mathrm{AVP}+\mathrm{NE}$ $10^{-7} \mathrm{M}$.

AVP alone). The addition of $\mathrm{PZ}\left(10^{-4} \mathrm{M}\right)$ to the bathing solution containing AVP and NE did not result in any significant change in $J_{\mathrm{v}}$ and $\mathrm{P}_{\mathrm{f}}$ which were $0.60 \pm 0.08 \mathrm{nl} \cdot \mathrm{min}^{-1} \cdot \mathrm{mm}^{-1}(P=\mathrm{NS}$ vs. AVP + NE) and $56.3 \pm 7.9 \times 10^{-4} \mathrm{~cm} / \mathrm{s}(P=$ NS vs. AVP $+\mathrm{NE})$, respectively. However, $J_{\mathrm{v}}$ and $\mathrm{P}_{\mathrm{f}}$ increased to $1.34 \pm 0.07$ $\mathrm{nl} \cdot \mathrm{min}^{-1} \cdot \mathrm{mm}^{-1}(P<0.005$ vs. AVP $+\mathrm{NE}+\mathrm{PZ})$ and $137.8 \pm 6.11 \times 10^{-4} \mathrm{~cm} / \mathrm{s}(P<0.001$ vs. AVP $+\mathrm{NE}+\mathrm{PZ})$, respectively, when $\mathrm{NE}$ and $\mathrm{PZ}$ were removed from the bathing solution and the tubules were studied in the presence of AVP alone. These values are not statistically different from those obtained during the initial experimental period, with AVP alone.

Group $V$. The effect of $\mathrm{Y}$ on NE-induced decreased in $J_{v}$ and $P_{f}$ was examined in this group of tubules $(n=4)$. As shown in Table IV, the presence of AVP $(100 \mu \mathrm{U} / \mathrm{ml})$ in the bathing solution resulted in a $J_{\mathrm{v}}$ of $1.48 \pm 0.05 \mathrm{nl} \cdot \mathrm{min}^{-1} \cdot \mathrm{mm}^{-1}$ and $\mathrm{P}_{\mathrm{f}}$ of $156.2 \pm 8.3 \times 10^{-4} \mathrm{~cm} / \mathrm{s}$. As in group IV, the addition of NE $\left(10^{-6} \mathrm{M}\right)$ resulted in a significant decrease in $J_{v}$ to $0.70 \pm 0.09$ $\mathrm{nl} \cdot \mathrm{min}^{-1} \cdot \mathrm{mm}^{-1}(P<0.01$ vs. AVP alone $)$ and in $P_{\mathrm{f}}$ to $67.8 \pm 10.5 \times 10^{-4} \mathrm{~cm} / \mathrm{s}(P<0.005$ vs. AVP alone $)$. However, the addition of $Y\left(10^{-6} \mathrm{M}\right)$ to the bathing solution resulted in a significant increase in $J_{\mathrm{v}}$ and $\mathrm{P}_{\mathrm{f}}$ to $1.41 \pm 0.09 \mathrm{nl} \cdot \mathrm{min}^{-1} \cdot \mathrm{mm}^{-1}$ $(P<0.025$ vs. AVP + NE, $P=$ NS vs. AVP alone $)$ and $147.8 \pm 11.0 \times 10^{-4} \mathrm{~cm} / \mathrm{s}(P<0.01$ vs. AVP $+\mathrm{NE}, P=\mathrm{NS}$ vs. AVP alone), respectively. Increasing the concentration of $Y$ to $10^{-5} \mathrm{M}$ did not result in any further significant increase in $J_{\mathrm{v}}$ and $P_{f}$, which were $1.54 \pm 0.09 \mathrm{nl} \cdot \mathrm{min}^{-1} \cdot \mathrm{mm}^{-1}$ and $163 \pm 7.3$ $\times 10^{-4} \mathrm{~cm} / \mathrm{s}$, respectively.

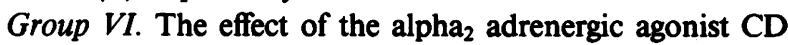
on AVP-induced $J_{v}$ and $P_{f}$ was examined in this group of tubules. As shown in Table $\mathrm{V}$, in the presence of maximal concentrations $(10 \mu \mathrm{U} / \mathrm{ml}$ ) of AVP (Group Vla, $n=5$ ) in the bathing solution, $J_{\mathrm{v}}$ and $\mathrm{P}_{\mathrm{f}}$ were $1.65 \pm 0.04 \mathrm{nl} \cdot \mathrm{min}^{-1} \cdot \mathrm{mm}^{-1}$ and $175.1 \pm 13.1$ $\times 10^{-4} \mathrm{~cm} / \mathrm{s}$, respectively. When $C D$ was added to the bathing solution in a concentration of $10^{-6} \mathrm{M}$, there was a significant

Table III. Effect of NE and PZ on AVP-induced $J_{v}$ and $P_{f}$ in the CCT of Rabbit

\begin{tabular}{|c|c|c|c|c|c|c|c|c|c|c|c|c|}
\hline & \multicolumn{3}{|c|}{ AVP $100 \mu \mathrm{U} / \mathrm{ml}$} & \multicolumn{3}{|c|}{ AVP $100 \mu \mathrm{U} / \mathrm{ml}+\mathrm{NE} 10^{-6} \mathrm{M}$} & \multicolumn{3}{|c|}{$\begin{array}{c}\text { AVP } 100 \mu \mathrm{U} / \mathrm{ml}+\mathrm{NE} 10^{-6} \mathrm{M} \\
+\mathrm{PZ} 10^{-4} \mathrm{M}\end{array}$} & \multicolumn{3}{|c|}{ AVP $100 \mu \mathrm{U} / \mathrm{ml}$} \\
\hline & $J_{v}$ & $\mathbf{P}_{\mathbf{r}}$ & $V_{1}$ & $J_{\mathrm{v}}$ & $\mathbf{P r}_{\mathbf{r}}$ & $V_{\mathbf{i}}$ & $J_{\mathrm{v}}$ & $\mathbf{P r}_{\mathrm{f}}$ & $V_{\mathrm{i}}$ & $J_{v}$ & $\mathbf{P}_{\mathbf{f}}$ & $V_{\mathbf{i}}$ \\
\hline & 1.38 & 150.4 & 10.7 & 0.56 & 52.9 & 10.0 & 0.54 & 51.1 & 10.2 & 1.19 & 123.0 & 11.0 \\
\hline & 1.37 & 144.4 & 10.7 & 0.50 & 46.8 & 10.4 & 0.50 & 47.1 & 10.8 & 1.28 & 132.4 & 10.1 \\
\hline & 1.48 & 158.0 & 10.0 & 0.56 & 52.5 & 10.1 & 0.83 & 79.7 & 9.7 & 1.42 & 147.6 & 9.8 \\
\hline & 1.61 & 163.2 & 9.6 & 0.54 & 49.7 & 9.8 & 0.52 & 47.1 & 9.8 & 1.48 & 148.0 & 9.6 \\
\hline Mean & 1.46 & 154.0 & 10.3 & $0.54^{*}$ & $50.5 \ddagger$ & $10.1 \S$ & $0.60^{\prime \prime}$ & $56.3^{\prime \prime}$ & $10.1 \S$ & $1.34 \pi$ & $137.8 \pi$ & $10.1 \S$ \\
\hline$\pm \mathrm{SE}$ & 0.06 & 4.1 & 0.3 & 0.01 & 1.4 & 0.1 & 0.08 & 7.9 & 0.3 & 0.07 & 6.1 & 0.3 \\
\hline
\end{tabular}

Tubules were studied at $25^{\circ} \mathrm{C}$ with a 165 mosmol/ $/ \mathrm{kg} \mathrm{H}_{2} \mathrm{O}$ transepithelial osmotic gradient. $J_{\mathrm{v}}$ is given in nanoliters per minute per millimeter; $P_{f}$, in $\times 10^{-4}$ centimeters per second; and $V_{i}$, in nanoliters per minute. Mean length of the tubules is $2.1 \mathrm{~mm}$. $* P<0.005$ vs. AVP alone. $\ddagger P<0.001$ vs. AVP alone. $\S P=$ not significant vs. AVP alone. "P $=$ not significant vs. AVP $+\mathrm{NE} 10^{-6} \mathrm{M}$. $\pi P<0.005$ vs. AVP NE + PZ. 
Table IV. Effect of NE and $Y$ on AVP-induced $J_{v}$ and $P_{f}$ in the CCT of Rabbit

\begin{tabular}{|c|c|c|c|c|c|c|c|c|c|c|c|c|}
\hline & \multicolumn{3}{|c|}{ AVP $100 \mu \mathrm{U} / \mathrm{ml}$} & \multicolumn{3}{|c|}{ AVP $100 \mu \mathrm{U} / \mathrm{ml}+\mathrm{NE} 10^{-6} \mathrm{M}$} & \multicolumn{3}{|c|}{$\begin{array}{c}\text { AVP } 100 \mu \mathrm{U} / \mathrm{ml}+\mathrm{NE} 10^{-6} \mathrm{M}+\mathrm{Y} \\
10^{-6} \mathrm{M}\end{array}$} & \multicolumn{3}{|c|}{$\begin{array}{c}\text { AVP } 100 \mu \mathrm{U} / \mathrm{ml}+\mathrm{NE} 10^{-6} \mathrm{M}+\mathrm{Y} \\
10^{-5} \mathrm{M}\end{array}$} \\
\hline & $J_{\mathrm{v}}$ & $P_{f}$ & $V_{\mathrm{i}}$ & $J_{\mathrm{v}}$ & $P_{f}$ & $V_{\mathrm{i}}$ & $J_{v}$ & $P_{r}$ & $V_{\mathrm{i}}$ & $J_{v}$ & $\mathbf{P}_{\mathbf{f}}$ & $V_{\mathrm{i}}$ \\
\hline & 1.42 & 135.9 & 12.4 & 0.60 & 55.4 & 12.2 & 1.49 & 145.7 & 11.9 & 1.62 & 158.9 & 10.9 \\
\hline & 1.60 & 172.4 & 9.1 & 0.54 & 50.8 & 9.1 & 1.60 & 173.6 & 8.8 & 1.75 & 183.7 & 9.0 \\
\hline & 1.40 & 150.1 & 9.7 & 0.71 & 67.3 & 9.9 & 1.16 & 120.1 & 9.2 & 1.36 & 149.4 & 8.8 \\
\hline & 1.50 & 166.5 & 10.1 & 0.96 & 97.5 & 9.3 & 1.39 & 151.8 & 9.8 & 1.44 & 160.0 & 9.7 \\
\hline Mean & 1.48 & 156.2 & 10.3 & $0.70^{*}$ & $67.8 \ddagger$ & $10.1 \S$ & $1.41 \S^{\| \prime}$ & $147.8 \S$ & $9.9 \S$ & $1.54 \S$ & $163.0 \S$ & $9.6 \S$ \\
\hline$\pm \mathrm{SE}$ & 0.05 & 8.3 & 0.7 & 0.09 & 10.5 & 0.7 & 0.09 & 11.0 & 0.7 & 0.09 & 7.3 & 0.5 \\
\hline
\end{tabular}

Tubules were studied at $25^{\circ} \mathrm{C}$ with a 165 mosmol/ $\mathrm{kg} \mathrm{H} \mathrm{H}_{2} \mathrm{O}$ transepithelial osmotic gradient. $J_{\mathrm{v}}$ is given in nanoliters per minute per millimeter; $\mathrm{P}_{\mathrm{f}}$, in $\times 10^{-4}$ centimeters per second; and $\mathrm{V}_{\mathrm{i}}$, in nanoliters per minute. Mean length of the tubules is $2.0 \mathrm{~mm} .{ }^{*} P<0.01$ vs. AVP alone. $\ddagger P$ $<0.005$ vs. AVP alone. $\S P=$ not significant vs. AVP alone. " $P<0.01$ vs. AVP $+\mathrm{NE} 10^{-6} \mathrm{M}$.

decrease in $J_{\mathrm{v}}$ to $1.08 \pm 0.12 \mathrm{nl} \cdot \mathrm{min}^{-1} \cdot \mathrm{mm}^{-1}(P<0.01 \mathrm{vs}$. AVP alone) and in $P_{\mathrm{f}}$ to $108.1 \pm 15.4 \times 10^{-4} \mathrm{~cm} / \mathrm{s}(P<0.01$ vs. AVP alone). When the concentration of $C D$ was increased to $10^{-5} \mathrm{M}$, there was a further significant decrease in $J_{\mathrm{v}}$ to $0.71 \pm 0.20$ $\mathrm{nl} \cdot \mathrm{min}^{-1} \cdot \mathrm{mm}^{-1}\left(P<0.05\right.$ vs. CD $\left.10^{-6} \mathrm{M}\right)$ but not in $\mathbf{P}_{\mathrm{f}}$ $\left(89.6 \pm 16.8 \times 10^{-4} \mathrm{~cm} / \mathrm{s}, P=\mathrm{NS}\right.$ vs. CD $\left.10^{-6} \mathrm{M}\right)$. Increasing the concentration of $\mathrm{CD}$ to $10^{-4} \mathrm{M}$, however, resulted in a further significant decrease in both $J_{\mathrm{v}}$ and $\mathrm{P}_{\mathrm{f}}$, which were $0.57 \pm 0.13 \mathrm{nl} \cdot \mathrm{min}^{-1} \cdot \mathrm{mm}^{-1}\left(P<0.02\right.$ vs. $\left.\mathrm{CD} 10^{-6} \mathrm{M}\right)$ and $54.7 \pm 13.8 \times 10^{-4} \mathrm{~cm} / \mathrm{s}\left(P<0.01\right.$ vs. $\left.\mathrm{CD} 10^{-6} \mathrm{M}\right)$, respectively. When $C D$ was removed from the bathing solution and the tubules were studied in the presence of AVP alone, there was a significant increase in $J_{\mathrm{v}}$ to $1.62 \pm 0.07 \mathrm{nl} \cdot \mathrm{min}^{-1} \cdot \mathrm{mm}^{-1}(P$ $<0.001$ vs. AVP $\left.+\mathrm{CD} 10^{-4} \mathrm{M}\right)$ and $\mathrm{P}_{\mathrm{f}}$ increased to $168.3 \pm 6.6$ $\times 10^{-4} \mathrm{~cm} / \mathrm{s}\left(P<0.001\right.$ vs. AVP $\left.+\mathrm{CD} 10^{-4} \mathrm{M}\right)$. These values are not different from those obtained during the initial experimental period, in the presence of AVP alone.

The effect of CD on $J_{v}$ and $P_{f}$ in the presence of supramaximal concentrations $(100 \mu \mathrm{U} / \mathrm{ml})$ of AVP is shown in Table VI (Group VIb, $n=5$ ). $J_{\mathrm{v}}$ and $\mathrm{P}_{\mathrm{f}}$ were $1.66 \pm 0.03 \mathrm{nl} \cdot \mathrm{min}^{-1} \cdot \mathrm{mm}^{-1}$ and $215.0 \pm 12.7 \times 10^{-4} \mathrm{~cm} / \mathrm{s}$, respectively, in the presence of AVP alone. The addition of $\mathrm{CD}\left(10^{-6} \mathrm{M}\right)$ to the bathing solution in the presence of AVP resulted in an insignificant decrease in $J_{\mathrm{v}}$ to $1.50 \pm 0.03 \mathrm{nl} \cdot \mathrm{min}^{-1} \cdot \mathrm{mm}^{-1}(P=\mathrm{NS}$ vs. AVP alone $)$ and a significant decrease in $P_{f}$ to $188.7 \pm 16.1 \times 10^{-4} \mathrm{~cm} / \mathrm{s}$ $(P<0.05$ vs. AVP alone). Increasing the concentration of $\mathrm{CD}$ to $10^{-5} \mathrm{M}$ resulted in a further significant decrease in $J_{\mathrm{v}}$ and $\mathrm{P}_{\mathrm{f}}$ to $1.28 \pm 0.12 \mathrm{nl} \cdot \mathrm{min}^{-1} \cdot \mathrm{mm}^{-1}\left(P<0.05\right.$ vs. $\left.\mathrm{CD} 10^{-6} \mathrm{M}\right)$ and $155.2 \pm 16.6 \times 10^{-4} \mathrm{~cm} / \mathrm{s}\left(P<0.025\right.$ vs. $\left.\mathrm{CD} 10^{-6} \mathrm{M}\right)$, respectively. When $\mathrm{CD}\left(10^{-4} \mathrm{M}\right)$ was added to the bathing solution, there was a further significant decrease in $J_{\mathrm{v}}$ to $0.86 \pm 0.11$ $\mathrm{nl} \cdot \mathrm{min}^{-1} \cdot \mathrm{mm}^{-1}\left(P<0.01\right.$ vs. CD $\left.10^{-5} \mathrm{M}\right)$ and in $\mathrm{P}_{\mathrm{f}}$ to $98.1 \pm 18.4 \times 10^{-4} \mathrm{~cm} / \mathrm{s}\left(P<0.005\right.$ vs. $\left.C D 10^{-5} \mathrm{M}\right) . J_{\mathrm{v}}$ increased to $1.49 \pm 0.06 \mathrm{nl} \cdot \mathrm{min}^{-1} \cdot \mathrm{mm}^{-1}\left(P<0.005\right.$ vs. AVP $+\mathrm{CD} 10^{-4}$ $\mathrm{M}, P=\mathrm{NS}$ vs. AVP alone), when CD was removed from the bathing solution and the tubules were studied in the presence

Table V. Effect of CD on AVP-induced $J_{v}$ and $P_{f}$ in the CCT of Rabbit

\begin{tabular}{|c|c|c|c|c|c|c|c|c|c|c|c|c|c|c|c|}
\hline & \multicolumn{3}{|c|}{ AVP $10 \mu \mathrm{U} / \mathrm{ml}$} & \multicolumn{3}{|c|}{ AVP $\underset{10 \mu \mathrm{U} / \mathrm{ml}}{10^{-6} \mathrm{M}}+\mathrm{CD}$} & \multicolumn{3}{|c|}{$\begin{array}{c}\text { AVP } 10 \mu \mathrm{U} / \mathrm{ml}+\mathrm{CD} \\
10^{-5} \mathrm{M}\end{array}$} & \multicolumn{3}{|c|}{ AVP $\underset{10 \mu \mathrm{U} / \mathrm{ml}}{10^{-4} \mathrm{M}}+\mathrm{CD}$} & \multicolumn{3}{|c|}{ AVP $10 \mu \mathrm{U} / \mathrm{ml}$} \\
\hline & $J_{v}$ & $P_{f}$ & $V_{\mathrm{i}}$ & $J_{v}$ & $P_{f}$ & $V_{\mathrm{i}}$ & $J_{v}$ & $\mathbf{P}_{\mathbf{f}}$ & $V_{\mathrm{i}}$ & $J_{v}$ & $\mathbf{P}_{\mathbf{f}}$ & $V_{\mathrm{i}}$ & $J_{v}$ & $P_{f}$ & $V_{\mathrm{i}}$ \\
\hline & 1.82 & 226.9 & 11.9 & 1.38 & 154.5 & 10.7 & 1.33 & 143.8 & 11.5 & 0.92 & 94.3 & 10.2 & 1.54 & 178.8 & 11.1 \\
\hline & 1.56 & 162.0 & 12.2 & 1.28 & 128.5 & 12.2 & 1.10 & 108.5 & 11.6 & 0.82 & 79.8 & 10.5 & 1.46 & 149.8 & 12.1 \\
\hline & 1.60 & 157.4 & 14.1 & 1.12 & 107.1 & 13.8 & 0.88 & 83.7 & 13.1 & 0.48 & 43.5 & 13.5 & 1.85 & 187.4 & 13.7 \\
\hline & 1.66 & 168.3 & 12.6 & 0.79 & 74.5 & 12.0 & 0.68 & 60.7 & 12.2 & 0.35 & 31.9 & 12.1 & 1.60 & 162.0 & 12.4 \\
\hline & 1.62 & 161.0 & 10.8 & 0.81 & 76.0 & 11.4 & 0.56 & 51.3 & 10.1 & 0.27 & 23.9 & 11.7 & 1.63 & 163.5 & 10.8 \\
\hline Mean & 1.65 & 175.1 & 12.3 & $1.08^{*}$ & $108.1^{*}$ & $12.0 \ddagger$ & $0.71 \S$ & 89.6 & $11.7 \ddagger$ & $0.57^{\prime \prime}$ & $54.7^{\prime \prime}$ & $11.6 \ddagger$ & $1.62 \ddagger$ & $168.3 \ddagger$ & $12.0 \ddagger$ \\
\hline$\pm \mathrm{SE}$ & 0.04 & 13.1 & 0.5 & 0.12 & 15.4 & 0.5 & 0.20 & 16.8 & 0.5 & 0.13 & 13.8 & 0.6 & 0.07 & 6.6 & 0.5 \\
\hline
\end{tabular}

Tubules were studied at $25^{\circ} \mathrm{C}$ with a $165 \mathrm{mosmol} / \mathrm{kg} \mathrm{H}_{2} \mathrm{O}$ transepithelial osmotic gradient. $J_{\mathrm{v}}$ is given in nanoliters per minute per millimeter; $\mathrm{P}_{\mathrm{f}}$, in $\times 10^{-4}$ centimeter per second; and $V_{\mathrm{i}}$, in nanoliters per minute. Mean length of the tubules is $2.0 \mathrm{~mm}$. ${ }^{*} P<0.001 \mathrm{vs}$. AVP alone. $¥ P$ $=$ not significant vs. AVP alone. $\S P<0.05$ vs. AVP $+\mathrm{CD} 10^{-6} \mathrm{M}$. $" P<0.025$ vs. AVP $+\mathrm{CD} 10^{-5} \mathrm{M}$. 
Table VI. Effect of CD on AVP-induced $J_{v}$ and $P_{f}$ in the CCT of Rabbit

\begin{tabular}{|c|c|c|c|c|c|c|c|c|c|c|c|c|c|c|c|}
\hline & \multicolumn{3}{|c|}{ AVP $100 \mu \mathrm{U} / \mathrm{ml}$} & \multicolumn{3}{|c|}{$\begin{array}{c}\text { AVP } 100 \mu \mathrm{U} / \mathrm{ml}+\mathrm{CD} \\
10^{-6} \mathrm{M} \\
\end{array}$} & \multicolumn{3}{|c|}{$\begin{array}{c}\text { AVP } 100 \mu \mathrm{U} / \mathrm{ml}+\mathrm{CD} \\
10^{-5} \mathrm{M}\end{array}$} & \multicolumn{3}{|c|}{$\begin{array}{c}\text { AVP } 100 \mu \mathrm{U} / \mathrm{ml}+\mathrm{CD} \\
10^{-4} \mathrm{M}\end{array}$} & \multicolumn{3}{|c|}{ AVP $100 \mu \mathrm{U} / \mathrm{ml}$} \\
\hline & $J_{\mathrm{v}}$ & $P_{r}$ & $V_{\mathbf{i}}$ & $J_{v}$ & $\mathbf{P}_{\mathrm{f}}$ & $V_{\mathrm{i}}$ & $J_{v}$ & $\mathbf{P}_{\mathbf{f}}$ & $V_{\mathrm{i}}$ & $J_{\mathrm{v}}$ & $\mathbf{P}_{\mathbf{r}}$ & $v_{\mathrm{i}}$ & $J_{v}$ & $\mathbf{P}_{\mathbf{f}}$ & $V_{\mathrm{i}}$ \\
\hline & 1.55 & 198.6 & 8.9 & 1.49 & 185.3 & 9.2 & 1.30 & 159.4 & 8.1 & 1.05 & 123.0 & 7.3 & 1.35 & 168.1 & 8.1 \\
\hline & 1.67 & 263.5 & 7.9 & 1.57 & 245.8 & 7.6 & 1.45 & 213.0 & 7.9 & 1.16 & 154.3 & 8.4 & 1.69 & 286.7 & 7.6 \\
\hline & 1.65 & 210.8 & 9.8 & 1.45 & 175.0 & 9.2 & 1.24 & 142.5 & 8.6 & 0.76 & 80.8 & 7.6 & 1.47 & 179.0 & 9.2 \\
\hline & 1.67 & 211.0 & 10.3 & 1.56 & 190.2 & 10.4 & 1.30 & 150.3 & 9.3 & 0.82 & 84.7 & 8.6 & 1.56 & 190.0 & 10.3 \\
\hline & 1.76 & 191.2 & 9.5 & 1.42 & 147.4 & 9.1 & 1.12 & 110.9 & 9.5 & 0.52 & 47.8 & 9.3 & 1.39 & 145.5 & 8.7 \\
\hline Mean & 1.66 & 215.0 & 9.3 & 1.50 & $188.7^{*}$ & $9.1 \ddagger$ & $1.28 \S$ & $155.2 \S$ & $8.7 \ddagger$ & 0.86 & $98.1^{11}$ & $8.3 \ddagger$ & $1.49 \ddagger$ & $193.9 \ddagger$ & $8.8 \ddagger$ \\
\hline$\pm \mathrm{SE}$ & 0.03 & 12.7 & 0.4 & 0.03 & 16.1 & 0.4 & 0.05 & 16.6 & 0.3 & 0.11 & 18.4 & 0.4 & 0.06 & $24.3^{\circ}$ & 0.5 \\
\hline
\end{tabular}

Tubules were studied at $25^{\circ} \mathrm{C}$ with a $165 \mathrm{mosmol} / \mathrm{kg} \mathrm{H}_{2} \mathrm{O}$ transepithelial osmotic gradient. $J_{\mathrm{v}}$ is given in nanoliters per minute per millimeter; $\mathrm{P}_{\mathrm{f}}$, in $\times 10^{-4}$ centimeters per second; and $\mathrm{V}_{\mathrm{i}}$, in nanoliters per minute. Mean length of the tubules is $2.4 \mathrm{~mm}$. ${ }^{*} P<0.05 \mathrm{vs}$. AVP alone. $\ddagger P$ $=$ not significant vs. AVP alone. $\S P<0.05$ vs. AVP + CD $10^{-6} \mathrm{M}$. $" P<0.005$ vs. AVP + CD $10^{-5} \mathrm{M}$.

of AVP alone. Similarly, $P_{f}$ increased to $193.9 \pm 24.3 \times 10^{-4}$ $\mathrm{cm} / \mathrm{s}\left(P<0.001\right.$ vs. AVP $+\mathrm{CD} 10^{-4} \mathrm{M}, P=$ NS vs. AVP alone).

Group VII. To determine whether the effect of $\mathrm{CD}$ was specific, the effect of the alpha ${ }_{2}$ adrenergic antagonist $Y$ on CDinduced decrease in water absorption was studied in this group of tubules $(n=4)$. As depicted in Fig. $2, J_{\mathrm{v}}$ and $\mathrm{P}_{\mathrm{f}}$ were $1.64 \pm 0.10$ $\mathrm{nl} \cdot \mathrm{min}^{-1} \cdot \mathrm{mm}^{-1}$ and $190.2 \pm 12.1 \times 10^{-4} \mathrm{~cm} / \mathrm{s}$, respectively, in the presence of $\operatorname{AVP}(100 \mu \mathrm{U} / \mathrm{ml})$ alone. Addition of $\operatorname{CD}\left(10^{-4}\right.$ $M)$ resulted in a significant decrease in $J_{v}$ to $0.42 \pm 0.04$ $\mathrm{nl} \cdot \mathrm{min}^{-1} \cdot \mathrm{mm}^{-1} \quad(P<0.001$ vs. AVP alone $)$ and in $P_{\mathrm{f}}$ to $38.7 \pm 4.3 \times 10^{-4} \mathrm{~cm} / \mathrm{s}(P<0.001$ vs. AVP alone $)$. The addition of $\mathrm{Y}\left(10^{-6} \mathrm{M}\right)$ resulted in a significant increase in $J_{\mathrm{v}}$ and $\mathrm{P}_{\mathrm{f}}$ to

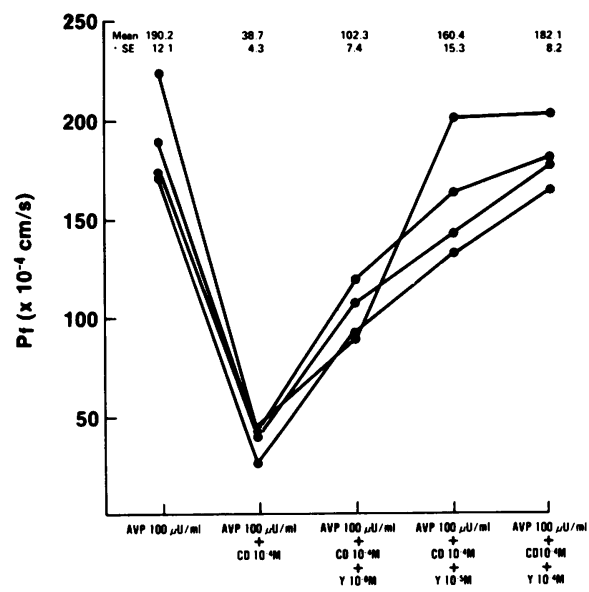

Figure 2. Effect of CD and Y on AVP-mediated water absorption in the CCT of rabbit. Mean length of the tubules is $2.5 \mathrm{~mm}$. There was no difference in the perfusion rate between the different experimental periods. Tubules were studied at $25^{\circ} \mathrm{C}$ with a $165 \mathrm{mosmol} / \mathrm{kg} \mathrm{H}_{2} \mathrm{O}$ transepithelial osmotic gradient. Closed circles and solid lines represent the values in individual tubules. Numbers on the top represent the mean $\pm \mathrm{SE}$ of the observations in the corresponding period.
$1.01 \pm 0.06 \mathrm{nl} \cdot \mathrm{min}^{-1} \cdot \mathrm{mm}^{-1}\left(P<0.02\right.$ vs. AVP $\left.+\mathrm{CD} 10^{-4} \mathrm{M}\right)$ and $102.3 \pm 7.4 \times 10^{-4} \mathrm{~cm} / \mathrm{s}\left(P<0.01\right.$ vs. AVP $\left.+\mathrm{CD} 10^{-4} \mathrm{M}\right)$, respectively. Increasing the concentration of $Y$ to $10^{-5} \mathrm{M}$ resulted in a further significant increase in $J_{\mathrm{v}}$ to $1.45 \pm 0.11$ $\mathrm{nl} \cdot \mathrm{min}^{-1} \cdot \mathrm{mm}^{-1}\left(P<0.02\right.$ vs. Y $10^{-6} \mathrm{M}, P=\mathrm{NS}$ vs. AVP alone) and in $P_{f}$ to $160.4 \pm 15.3 \times 10^{-4} \mathrm{~cm} / \mathrm{s}(P<0.02$ vs. $Y$ $10^{-6} \mathrm{M}, P=\mathrm{NS}$ vs. AVP alone). Addition of $\mathrm{Y}\left(10^{-4} \mathrm{M}\right) \mathrm{did}$ not result in any further significant increase in $J_{\mathrm{v}}$ and $P_{\mathrm{f}}$, which were $1.60 \pm 0.06 \mathrm{nl} \cdot \mathrm{min}^{-1} \cdot \mathrm{mm}^{-1}\left(P=\mathrm{NS}\right.$ vs. $\left.\mathrm{Y} 10^{-5} \mathrm{M}\right)$ and $182.1 \pm 8.2 \times 10^{-4} \mathrm{~cm} / \mathrm{s}\left(P=\mathrm{NS}\right.$ vs. Y $\left.10^{-5} \mathrm{M}\right)$, respectively.

Group VIII. The effect of CD on cyclic AMP-induced water absorption was examined in this group of tubules $(n=4)$. The presence of 8-BrcAMP $\left(10^{-4} \mathrm{M}\right)$ in the bathing solution resulted in a $J_{v}$ of $1.48 \pm 0.08 \mathrm{nl} \cdot \mathrm{min}^{-1} \cdot \mathrm{mm}^{-1}$ and $P_{f}$ of $166.9 \pm 16.1$ $\times 10^{-4} \mathrm{~cm} / \mathrm{s}$. The addition of $\mathrm{CD}\left(10^{-4} \mathrm{M}\right)$ to the bathing solution containing 8-BrcAMP resulted in no change in $J_{\mathrm{v}}$ and $P_{f}$, which were $1.41 \pm 0.07 \mathrm{nl} \cdot \mathrm{min}^{-1} \cdot \mathrm{mm}^{-1}$ and $155.3 \pm 17.0$ $\times 10^{-4} \mathrm{~cm} / \mathrm{s}$, respectively (Table VII).

Group IX. In this group of tubules $(n=2)$, in the presence of $\operatorname{AVP}(100 \mu \mathrm{U} / \mathrm{ml}) J_{\mathrm{v}}$ and $P_{\mathrm{f}}$ were $1.64 \pm 0.09 \mathrm{nl} \cdot \mathrm{min}^{-1} \cdot \mathrm{mm}^{-1}$ and $177.7 \pm 18.5 \times 10^{-4} \mathrm{~cm} / \mathrm{s}$, respectively. Addition of $\mathrm{PZ}\left(10^{-4}\right.$ $\mathrm{M})$, in the presence of AVP did not result in any significant change in $J_{v}$ and $P_{f}$, which were $1.57 \pm 0.01 \mathrm{nl} \cdot \mathrm{min}^{-1} \cdot \mathrm{mm}^{-1}$ $(P=$ NS vs. AVP alone $)$ and $167.7 \pm 4.5 \times 10^{-4} \mathrm{~cm} / \mathrm{s}(P=\mathrm{NS}$ vs. AVP alone), respectively. Similarly, the addition of PR $\left(10^{-4}\right.$ $\mathrm{M})$ or $\mathrm{Y}\left(10^{-4} \mathrm{M}\right)$ did not result in any significant change in $J_{\mathrm{v}}$ or $\mathrm{P}_{\mathrm{f}}$. In the presence of PR $\left(10^{-4} \mathrm{M}\right), J_{\mathrm{v}}$ was $1.55 \pm 0.01$ $\mathrm{nl} \cdot \mathrm{min}^{-1} \cdot \mathrm{mm}^{-1}(P=\mathrm{NS}$ vs. AVP alone $)$ and $P_{\mathrm{f}}$ was $163.9 \pm 4.5$ $\times 10^{-4} \mathrm{~cm} / \mathrm{s}(P=\mathrm{NS}$ vs. AVP alone). In the presence of $\mathrm{Y}$ $\left(10^{-4} \mathrm{M}\right), J_{\mathrm{v}}$ was $1.57 \pm 0.08 \mathrm{nl} \cdot \mathrm{min}^{-1} \cdot \mathrm{mm}^{-1}(P=\mathrm{NS}$ vs. AVP alone) and $P_{f}, 166.4 \pm 13.6 \times 10^{-4} \mathrm{~cm} / \mathrm{s}(P=N S$ vs. AVP alone $)$.

\section{Discussion}

Catecholamines modulate several aspects of renal function including the renal blood flow, glomerular filtration, tubular 
Table VII. Effect of CD on 8-BrcAMP-mediated $J_{v}$ and $P_{f}$ in the CCT of Rabbit

\begin{tabular}{|c|c|c|c|c|c|c|}
\hline & \multicolumn{3}{|c|}{ 8-BrcAMP $10^{-4} \mathrm{M}$} & \multicolumn{3}{|c|}{ 8-BrcAMP $10^{-4} \mathrm{M}+\mathrm{CD} 10^{-4} \mathrm{M}$} \\
\hline & $J_{v}$ & $\mathbf{P}_{\mathbf{f}}$ & $v_{\mathrm{i}}$ & $J_{\mathrm{v}}$ & $P_{f}$ & $v_{\mathrm{i}}$ \\
\hline & 1.57 & 198.8 & 7.7 & 1.59 & 202.2 & 7.7 \\
\hline & 1.65 & 181.2 & 7.3 & 1.43 & 147.9 & 7.8 \\
\hline & 1.27 & 123.5 & 11.1 & 1.24 & 120.9 & 10.4 \\
\hline & 1.43 & 164.0 & 8.2 & 1.36 & 150.3 & 8.5 \\
\hline Mean & 1.48 & 166.9 & 8.6 & $1.41^{*}$ & $155.3^{*}$ & $8.6^{*}$ \\
\hline$\pm \mathrm{SE}$ & 0.08 & 16.1 & 0.9 & 0.07 & 17.0 & 0.6 \\
\hline
\end{tabular}

Tubules were studied at $25^{\circ} \mathrm{C}$ with a $165 \mathrm{mosmol} / \mathrm{kg} \mathrm{H}_{2} \mathrm{O}$ transepithelial osmotic gradient. $J_{\mathrm{v}}$ is given in nanoliters per minute per millimeter; $\mathrm{P}_{\mathrm{f}}$, in $\times 10^{-4}$ centimeters per second; and $V_{\mathrm{i}}$, in nanoliters per minute. Mean length of the tubules is $1.9 \mathrm{~mm}$. ${ }^{*} P=$ not significant vs. AVP alone.

transport, and the release of renin (1). The effect of catecholamines on water absorption has drawn the attention of several investigators. There is evidence to suggest that alpha adrenergic stimulation increases $\mathrm{C}_{\mathrm{H}_{2} \mathrm{O}}$ (14-16). On the other hand, beta adrenergic stimulation has been shown to cause antidiuresis ( 1 , 17). The exact mechanism by which catecholamines cause changes in water excretion, however, is unclear. Some of the previous studies have suggested that these agents cause changes in water excretion by modifying the release of endogenous vasopressin, whereas others have suggested that these agents modify the action of AVP at the cellular level (1). Using isolated segments of the rabbit CCT that were perfused in vitro, we have recently demonstrated that the alpha adrenergic agonist PE directly inhibits AVP-mediated water absorption at the tubular level, an effect that can be blocked by a specific alpha adrenergic antagonist phentolamine (9). The inhibition of water absorption by PE seems to be through the inhibition of AVP-mediated cyclic AMP production (9).

The alpha adrenergic receptors can be subdivided into alpha and alpha ${ }_{2}$ adrenergic receptors $(18,19)$. The recognition of the subtypes was preceded by the appreciation that they had a role in modulating the amount of catecholamine release from the nerve terminals. In general, alpha $\mathrm{l}_{1}$ receptors include typical postsynaptic receptors mediating smooth muscle contraction,

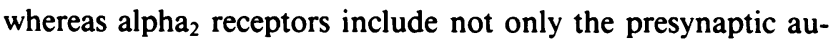
toregulatory alpha adrenergic receptors but also the postsynaptic receptors that are shown on the platelets (18). Because of the difficulties in using the anatomical classification, alpha adrenergic receptors are classified into subtypes based on their differences in affinity for various selective alpha adrenergic agonists and antagonists (19). In radioligand-binding studies, alpha $a_{1}$ adrenergic receptors can be identified by using an alpha $a_{1}$ adrenergic selective antagonist, $\left[{ }^{3} \mathrm{H}\right] \mathrm{PZ}$, whereas alpha ${ }_{2}$ adrenergic receptors can be identified by using an alpha ${ }_{2}$ adrenergic selective antagonist, $\left[{ }^{3} \mathrm{H}\right] \mathrm{Y}(20,21)$. Similarly, the role of the specific receptors can be defined by using the specific agonists and antagonists in functional studies (22).

In the kidney, both alpha $a_{1}$ and alpha $a_{2}$ receptors have been identified, with an apparent dominance of alpha $a_{2}$ adrenergic receptors by a factor of three to one (22). This work suggested that alpha $a_{1}$ adrenergic receptors are located on the vasculature and mediate the renal vasoconstriction. On the other hand, alpha $_{2}$ adrenergic receptors are located on the renal tubules (22). Similarly, radioligand binding has indicated that the alpha adrenergic receptors on the guinea pig proximal tubule are of alpha $_{2}$ adrenergic type $(23,24)$. The presence of alpha ${ }_{2}$ adrenergic receptors coupled to inhibition of parathyroid hormone-stimulated adenylate cyclase has been demonstrated in homogenates of rat renal cortex $(25,26)$. However, the functional role of these receptors and the specific type of alpha adrenergic receptors (alpha ${ }_{1}$ or alpha $a_{2}$ or both) involved in modulating AVP-induced water absorption, have not been identified. Using isolated rat CCT, Chabardes et al. (27) have shown in a preliminary report that the inhibition of AVP-induced cyclic AMP accumulation by nonspecific alpha adrenergic agonists can be blocked by $\mathrm{Y}$ but not by PZ. Therefore, the present studies were performed in isolated segments of rabbit CCT to characterize functionally the specific subtype of alpha adrenergic receptors involved in the modulation of the hydroosmotic effect of AVP. As in our previous studies (9), the results of the present studies indicate that alpha adrenergic stimulation with PE has a direct effect on the CCT to inhibit AVP-mediated water absorption. The present studies demonstrate further that this effect can be blocked only by the specific alpha $a_{2}$ adrenergic antagonist $Y$. On the other hand the alpha $a_{1}$ adrenergic antagonist $\mathrm{PZ}$ had no effect on the inhibition of AVP-mediated water absorption by PE. Neither $\mathrm{Y}$ nor PZ alone had any effect on AVP-mediated water absorption. The failure of high concentrations of $\mathrm{PZ}$ to antagonize the alpha adrenergic effect of $P E$ is in conflict with the radioligand studies that show displacement of $\left[{ }^{3} \mathrm{H}\right] \mathrm{CD}$ by high concentrations of $\mathrm{PZ}(23,24)$. The absence of a functional parallel to the radioligand-binding studies underscores the importance of functional studies in determining the biological meaning of physicochemical observations. It must be added, in this regard, that PZ did not block the inhibition of antidiuretic hormone-stimulated cyclic AMP accumulation in rat CCT induced by alpha adrenergic agonists (27), an observation that is in agreement with ours

In considering the effects of the catecholamines on renal function, it should be emphasized that NE is the neurotransmitter released at the sympathetic effector sites, whereas epinephrine is the principal circulating adrenergic hormone $(28,29)$. To determine whether the natural endogenous catecholamine NE exerts the same effect as that of PE, we examined the effect of NE on AVP-induced water absorption in CCT that were treated with PR to block the beta adrenergic effects of NE. Our results indicated that alpha adrenergic stimulation with $\mathrm{NE}$ also had a direct dose-dependent effect to inhibit AVP-mediated water absorption. PR alone had no effect on AVP-mediated water absorption, indicating that the effect seen in our experiments 
was indeed the result of the alpha adrenergic effect of NE. Also, the inhibitory effect of NE was blocked by Y, but not by PZ, pointing to activation of an alpha $a_{2}$ adrenergic receptor.

It may be argued that the effect of NE seen in our studies may be more pharmacologic than physiologic. Using fluorescence histochemical and electron microscopic techniques, adrenergic nerve terminals have been shown to be in direct contact with the basement membranes of the proximal and distal tubules in monkey, rat, and dog kidneys, and the thick ascending limb of Henle's loop in the rat kidney (30-33). More recently, L. Barajas (personal communication) demonstrated that the adrenergic nerve terminals are in close contact with the basement membranes of the CCT, also in the rat kidney. In view of this evidence, it can be assumed that the concentrations of $\mathrm{NE}\left(10^{-8}\right.$ $10^{-5} \mathrm{M}$ ) used in our studies may be physiologic since they fall in the range of concentrations present at nerve endings (34). It is quite possible, however, that the inhibitory effect of NE on water absorption becomes evident physiologically only in the conditions where there is maximal release of catecholamines in the kidney.

CD is a known alpha ${ }_{2}$ adrenergic agonist. Previous studies in anesthetized $\operatorname{dogs}(4,5)$ and rats $(3)$ have shown that the intravenous administration of CD causes increase in renal water excretion. This effect could be the result of a central inhibition of AVP release or inhibition of action of AVP on the renal tubule. Humphreys and Reid (4) could not detect any water diuresis when CD was infused intravenously into acutely hypophysectomized dogs. Their results indicated that CD causes water diuresis through inhibition of AVP release, possibly via an indirect pathway mediated by the alpha adrenergic effects of CD on the circulation. Reid and Keil (6) have shown decreased concentrations of plasma AVP in response to the administration of CD. Other investigators $(7,8)$, however, have failed to find any detectable changes in plasma AVP concentrations after the administration of clonidine. Solez et al. (8) have shown that intravenous administration of $\mathrm{CD}$ causes an increase in $\mathrm{C}_{\mathrm{H}_{2} \mathrm{O}}$, even when it was administered into rabbits that were pretreated with vasopressin tannate in oil, suggesting that $C D$ inhibits the antidiuretic action of AVP at the tubular level. The results of

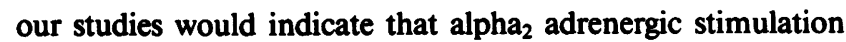
with CD has a direct, dose-dependent effect on the CCT to inhibit AVP-mediated water absorption, in the presence of maximal as well as supramaximal concentrations of AVP. This effect can be blocked by the specific alpha ${ }_{2}$ adrenoreceptor antagonist $Y$, while $Y$ alone has no effect on AVP-induced water absorption. These studies, therefore, provide the first evidence that an alpha adrenoreceptor can modulate renal tubular function. The inhibitory effect of $C D$ on water absorption may not be of physiologic importance to man, since it has not been shown to cause water diuresis in man. However, these observations definitely add strength to our studies, which demonstrate the specific role of alpha ${ }_{2}$ adrenergic receptors in inhibiting AVP-mediated water absorption.

Alpha $_{2}$ adrenergic stimulation has been shown to inhibit adenylate cyclase activity in the renal cortex and platelets (18,
25). The inhibition of water absorption by $C D$ appears to be through the inhibition of AVP-induced cyclic AMP generation, since CD has no effect on 8-BrcAMP-mediated water absorption. These findings are similar to those of our previous observations where PE was shown to have no effect on cyclic AMP-mediated water absorption. Alternatively, it is possible that alpha adrenoreceptor agonists may exert their inhibitory effect on the hydroosmotic response to antidiuretic hormone via an increase in cytosolic calcium. Two lines of evidence argue against this possibility. First, the effect of changes in cytosolic calcium on the hydroosmotic response of epithelia to antidiuretic hormone is controversial with both increases and decreases in cytosolic calcium causing depressed response $(35,36)$. Second, in the rabbit collecting tubule low peritubular sodium concentration, which raises cytosolic calcium activity, inhibited the hydroosmotic response to 8-[ $p$-chlorophenylthio]-cyclic 3',5'-adenosine monophosphate (37), whereas in our previous published study (9) and in the present study adrenoreceptor agonists did not.

In conclusion, the results of the present studies confirm our previous observation that alpha adrenergic stimulation directly inhibits AVP-mediated water absorption in the CCT. The native catecholamine NE exerts a similar effect to that of PE in vitro, even in the low concentrations in which it exists in vivo. The inhibitory effects of alpha adrenergic stimulation on AVP-mediated water absorption can be blocked only by specific alpha ${ }_{2}$ adrenergic antagonists, but not by alpha ${ }_{1}$ adrenergic antagonists, suggesting that the alpha ${ }_{2}$ adrenergic receptors are responsible for the inhibition of AVP-mediated water absorption, at the tubular level. In addition, alpha ${ }_{2}$ adrenergic stimulation with the specific agonist clonidine directly inhibited AVP-mediated water absorption, an effect that can be blocked by a specific alpha $a_{2}$ adrenergic antagonist. It appears that this effect was caused by inhibiting AVP-induced cyclic AMP production. An additional effect of alpha ${ }_{2}$ adrenergic stimulation to modify the release of endogenous vasopressin, however, cannot be excluded from our studies.

\section{Acknowledgments}

We acknowledge the valuable advice given by Dr. Yuth Nimit, Neuropharmacologist, Department of Neurochemistry, Veterans Administration Medical Center. We gratefully acknowledge the secretarial assistance of Daphne Guillory and Laura Brazil, and the technical assistance of Ernest Pace and Herbert Babino.

This investigation was supported by grants from the Veterans Administration Central Office, and from the National Institutes of Health (AM 21394).

\section{References}

1. Schrier, R. W. 1974. Effects of adrenergic nervous system and catecholamines on systemic and renal hemodynamics, sodium and water excretion and renin secretion. Kidney Int. 6:291-306.

2. Hoefke, W., and W. Kobinger. 1966. Pharmakologische Wirkungen des 2-(2,6-dichlorphenylamino)-2-imidazoline hydrochlorids einer neuen antihypertensiven Substanz. Arzneim. Forsch. 16:1038-1050. 
3. LeDouarec, J. C., H. Schmitt, and B. Lucet. 1971. Influence de la clonidine et des substances $\alpha$-sympathomimétiques sur la prise d'eau chez le rat assoiffe. J. Pharmacol. (Paris). 2:435-444.

4. Humphreys, M. H., and I. A. Reid. 1975. Suppression of antidiuretic hormone secretion by clonidine in the anesthetized dog. Kidney Int. 7:405-412.

5. Olsen, U. B. 1976. Clonidine-induced increase in renal prostaglandin activity and water diuresis in conscious dogs. Eur. J. Pharmacol. 36:95-101.

6. Reid, I. A., and L. C. Keil. 1977. Suppression of antidiuretic hormone secretion by clonidine. Clin. Res. 25:106A. (Abstr.)

7. Gullner, H. G. 1979. Lack of suppression of vasopressin plasma levels by catapres. Pharmacol. Res. Commun. 11:39-44.

8. Solez, K., T. Ideura, C. B. Silvia, B. Hamilton, and H. Saito. 1980. Clonidine after renal ischemia to lessen acute renal failure and microvascular damage. Kidney Int. 18:309-322.

9. Krothapalli, R. K., W. B. Duffy, H. O. Senekjian, and W. N. Suki. 1983. Modulation of the hydro-osmotic effect of vasopressin on the rabbit cortical collecting tubule by adrenergic agents. J. Clin. Invest. 72:287-294.

10. Burg, M. B., J. Grantham, M. Abramow, and J. Orloff. 1966. Preparation and study of fragments of single rabbit nephrons. Am. J. Physiol. 210:1293-1298.

11. Al-Zahid, G., J. A. Schafer, S. L. Troutman, and T. E. Andreoli. 1977. The effect of antidiuretic hormone on water and solute permeation, and the activation energies for these processes, in mammalian cortical collecting tubules. Evidence for parallel ADH-sensitive pathways for water and solute diffusion in luminal plasma membranes. J. Membr. Biol. 31:103-129.

12. Snedecor, G. W., and W. G. Cochran. 1980. Statistical methods. The Iowa State University Press, Ames, IA. 83-102.

13. Miller, S. L. 1981. Introductory statistics for dentistry and medicine. Reston Publishing Company, Inc., Reston, VA. 197-224.

14. Fisher, D. A. 1968. Norepinephrine inhibition of vasopressin antidiuresis. J. Clin. Invest. 47:540-547.

15. Schrier, R. W., and T. Berl. 1973. Mechanism of effect of alpha adrenergic stimulation with norepinephrine on renal water excretion. J. Clin. Invest. 52:502-511.

16. Berl, T., J. A. Harbottle, and R. W. Schrier. 1974. Effect of alpha- and beta-adrenergic stimulation on renal water excretion in man. Kidney Int. 6:247-253.

17. Schrier, R. W., R. Lieberman, and R. C. Ufferman. 1972. Mechanism of antidiuretic effect of beta-adrenergic stimulation. J. Clin. Invest. 51:97-111.

18. Hoffman, B. B., and R. J. Lefkowitz. 1980. Alpha-adrenergic receptor subtypes. N. Engl. J. Med. 302:1390-1396.

19. Starke, K., and J. R. Docherty. 1980. Recent developments in $\alpha$-adrenoceptor research. J. Cardiovasc. Pharmacol. 2(Suppl. 3): S269S286.

20. Doxey, J. C., C. F. C. Smith, and J. M. Walker. 1977. Selectivity of blocking agents for pre- and postsynaptic $\alpha$-adrenoceptors. $B r . J$. Pharmacol. 60:91-96.
21. U'Prichard, D. C., and S. H. Snyder. 1979. Distinct $\alpha$-noradrenergic receptors differentiated by binding and physiological relationships. Life Sci. 24:79-88.

22. Schmitz, J. M., R. M. Graham, A. Sagalowsky, and W. A. Pettinger. 1981. Renal alpha-1 and alpha-2 adrenergic receptors. Biochemical and pharmacological correlations. J. Pharmacol. Exp. Ther. 219:400406.

23. Jarrott, B., W. J. Louis, and R. J. Summers. 1979. The characteristics of $\left[{ }^{3} \mathrm{H}\right]$-clonidine binding to an $\alpha$-adrenoceptor in membranes from guinea-pig kidney. Br. J. Pharmacol. 65:663-670.

24. Young, W. S., and M. J. Kuhar. 1980. $\alpha_{2}$ adrenergic receptors are associated with renal proximal tubules. Eur. J. Pharmacol. 67:493495.

25. Woodcock, E. A., C. I. Johnston, and C. A. Olsson. 1980. Alphaadrenergic inhibition of renal cortical adenylate cyclase. J. Cyclic Nucleotide Res. 6:261-270.

26. Woodcock, E. A., and C. I. Johnston. 1982. Selective inhibition by epinephrine of parathyroid hormone-stimulated adenylate cyclase in rat renal cortex. Am. J. Physiol. 242:F721-F726.

27. Chabardes, D., M. Montegut, M. Imbert-Teboul, and F. Morel. 1982. $\alpha$-adrenergic agonist inhibits vasopressin (AVP) induced cAMP accumulation in the collecting tubule. Proceedings of the Annual Meeting of the American Society of Nephrology, 15th, Chicago. 158A. (Abstr.)

28. Insel, P. A., and M. D. Snavely. 1981. Catecholamines and the kidney. Receptors and renal function. Annu. Rev. Physiol. 43:625-636.

29. Moss, N. G. 1982. Renal function and renal afferent and efferent nerve activity. Am. J. Physiol. 243:F425-F433.

30. Muller, J., and L. Barajas. 1972. Electron microscopic and histochemical evidence for a tubular innervation in the renal cortex of the monkey. J. Ultrastruct. Res. 41:533-549.

31. Barajas, L., and J. Muller. 1973. The innervation of the juxtaglomerular apparatus and surrounding tubules. A quantitative analysis by serial section electron microscopy. J. Ultrastruct. Res. 43:107-132.

32. DiBona, G. F. 1977. Neurogenic regulation of renal tubular sodium reabsorption. Am. J. Physiol. 233:F73-F81.

33. Barajas, L., P. Wang, K. Powers, and S. Nishio. 1981. Identification of renal neuroeffector junctions by electron microscopy of reembedded light microscopic autoradiograms of semithin sections. $J$. Ultrastruct. Res. 77:379-385.

34. Dahlstrom, A., and J. Haggendal. 1966. Some quantitative studies on the noradrenaline content in the cell bodies and terminals of a sympathetic adrenergic neuron system. Acta Physiol. Scand. 67:271-277.

35. Hardy, M. A. 1978. Intracellular calcium as a modulator of transepithelial permeability to water in frog urinary bladder. J. Cell Biol. 76:787-791.

36. Humes, H. D., C. F. Simmons, Jr., and B. M. Brenner. 1980. Effect of verapamil on the hydroosmotic response to antidiuretic hormone in toad urinary bladder. Am. J. Physiol. 239:F250-F257.

37. Frindt, G., E. E. Windhager, and A. Taylor. 1982. Hydroosmotic response of collecting tubules to ADH or CAMP at reduced peritubular sodium. Am. J. Physiol. 243:F503-F513. 